\section{Історія Украӥни}

History of Ukraine
ISSN: 2411-6181(on-line); ISSN: 2311-9896 (print)

Current issues of social studies and history of medicine. Joint Ukrainian -Romanian scientific journal, 2021, №:2(30), P. 34-39

UDK 94(477.87)7919/1929."614.2

DOI $10.24061 / 2411-6181.2 .2021 .264$

\author{
СТАН ЛІКАРЕНЬ НА ПІДКАРПАТСЬКІЙ РУСІ УПРОДОВЖ \\ ПЕРШОГО ДЕСЯТИЛІТТЯ ЧЕХОСЛОВАЦЬКОГО \\ УРЯДУВАННЯ (1919 - 1929) \\ Ігор ЛІХТЕЙ, \\ Ужгородський національний університет, \\ Ужгород (Україна); lichtej@ukr.net
}

\title{
THE STATE OF HOSPITALS IN PIDKARPATSKA RUS DURING THE FIRST DECADE OF CZECHOSLOVAK RULE (1919-1929). Ihor LIKHTEI,
}

Uzhhorod National University, (Ukraine)

\begin{abstract}
Лихтей Игорь. Состояние больниц на Подкарпатской Руси на протяжении первого десятилетия чехословацкого правительства (1919-1929). В статье прослеживается процесс деятельности больниц Закарпатья в течение первого десятилетия пребывания края в составе Чехословакии. Методы исследования. Использовано прежде всего сравнительно-исторический и структурно-системный методы анализа, обобщения и синтеза, а также проблемно-хронологический способ изложения материала. Научная новизна. Обозначенная проблематика рассматривается в историографии впервые. Выводы. На момент включения Закарпатья в состав Чехословакии здесь было четыре крупных больницы, три из которых находились в весьма плачевном состоянии. Чехословацкой администрации пришлось прилагать немало усилий для их модернизации. В статье акцентировано внимание на деятельности врачей, которые прибывали в Закарпатье преимущественно из чешских и моравских земель. Они, как правило, были выпускниками медицинского факультета Пражского университета и благодаря их подвижнической работе произошло улучшение состояния больниц и медицинского обеспечения населения.
\end{abstract}

Ключевые слова. Чехословацкая республика, Подкарпатская Русь, Закарпатье, больницы, врачи, здравоохранение, медицинское обеспечение.

Постановка проблеми. У вересні 1919 р. Закарпаття стало складовою частиною новоутвореної Чехословацької республіки (ЧСР). У цій державі край отримав офіційну назву Підкарпатська Русь. Щоправда, підкарпатський люд у матеріальному й духовному плані був настільки знесилений $\mathrm{i}$ фізично поневолений, що навряд чи міг повірити в можливості цієї нової ситуації для покращення свого соціального й політичного становища. Чехословацькій адміністрації довелося вживати дієвих заходів задля надання якнайшвидшої допомоги, аби не допустити вимирання населення Підкарпатської Русі від голоду та епідемій, які загрожували й іншим, більш розвиненим у культурному плані, регіонам Європи, спустошеним у ході Першої світової війни. На той час мало хто усвідомлював, наскільки відповідальним і важким буде це важливе завдання, вирішення якого взяла на себе ЧСР ${ }^{1}$. Крім іншого, чехословацька влада активно стала наводити лад і в сфері охорони здоров'я.

В добу австро-угорського панування територію Підкарпатської Русі було поділено на 40 санітарних округів, у яких працювало 28 окружних і дільничних лікарів. У містах Ужгороді, Мукачеві, Берегові та Великому Севлюші (нині Виноградово) функціонували жупні лікарні, які були недостатньо обладнані і мали на балансі всього 800 ліжок. Крім того, в Ужгороді існувала школа акушерок на 12 ліжок для породіль. Щоправда, це був не лікувальний, а навчальний заклад. У кількох містах краю діяли окремі установи соціальної опіки: будинок глухонімих в Ужгороді, дитячий притулок у Мукачеві, заклад для дітей з психічними розладами у Великому Севлюші. Питанням надання систематичної медичної допомоги широким верствам населення австро-угорські урядовці майже не переймалися. Сільський люд зазвичай звертався по допомогу до знахарів, не надто довіряв лікарям і навіть побоювався їх. У селі лікаря можна було побачити хіба що під час проведення урядового щеплення від віспи, або коли 3 відчаю його запрошували до хворої людини, яка вже помирала ${ }^{2}$. Не останню роль у такому ставленні населення краю до фахової медицини відігравали і не надто привабливі умови в лікарнях. Тож перші лікарі, які прибули на Підкарпатську Русь 3 чеських і моравських земель, доклали чимало зусиль для того, аби змінити ситуацію на краще.

Історіографія. $\mathrm{y}$ міжвоєнний період питання функціонування лікарень краю у 20-ті роки $\mathrm{XX}$ ст. висвітлювали у своїх невеличких публікаціях самі медичні працівники. Йдеться про статті й замітки інформативного характеру таких лікарів, як Й. Дошкар, С. Веселий, М. Долинай, С. Микуланинець. У наші дні досить активно досліджується минуле Ужгородської лікарні. Ті чи інші аспекти

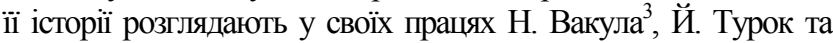

\footnotetext{
${ }^{1}$ Ulman Fr. "Dobrovolná sociáalně-zdravotní péče na Podkarp. Rusi” [Voluntary social and health care in Podkarp.Rusi], Publikace pro zem Podkarpatská Rus [Publications for the ground Subcarpathian Rus], sestavil Gustav Bianchi, Bánska Bystřica: Slovan, 1932, P. 73 [in Slovak].

${ }^{2}$ Mikulaninets S. "Zdravokhranenie i sotsial'no-sanitarnyya otnosheniya na Podkarpatskoy Rusi” [Health and social and sanitary relations in Subcarpathian Rus], Podkarpatskaya Rus' za gody 1919-1936 [Subcarpathian Rus during the years 1919-1936], red. E. S. Bachinskiy, Uzhgorod, Shkol'naya pomoshch', 1936, P. 71 [in Russian]; Mikulaninec Št. "Zdravotnictví a sociálně zdravotní poměry na Podkarpatské Rusi" [Healthcare and socio-health conditions in Subcarpathian Rus], Podkarpatská Rus. Sborník hospodářského, kulturního a politického poznáni Podkarpatské Rusi [Subcarpathian Rus. Proceedings of economic, cultural and political knowledge of Subcarpathian Rus], redigoval Dr. Jaroslav Zatloukal. Bratislava: Klub přátel Podkarpatské Rusi, 1936, P. 168-169 [in Slovak].

${ }^{3}$ Vakula N. S. "Andrii Novak - fundator Zakarpatskoi oblasnoi klinichnoi likarni. Do 165 richnytsi z dnia narodzhennia" [Andriy Novak is the founder of the Transcarpathian Regional Clinical Hospital. To the 165th anniversary of his birth], Naukovyi visnyk Uzhhorodskoho universytetu, seriia "Medytsyna" [Scientific Bulletin of Uzhhorod University, series "Medicine"], 2015, Vol. 1(51), P. 302-306 [in Ukrainian].
} 
Ю. Яцина ${ }^{4}$. Натомість вивчення діяльності інших лікарень Закарпаття поки що залишається поза увагою науковців.

Мета дослідження - проаналізувати стан лікарень, які функціонували в Ужгороді, Мукачеві, Берегові й Севлюші в австро-угорський період, а відтак простежити зміни, що відбулися в цих медичних установах упродовж першого десятиліття чехословацького урядування.

Виклад основного матеріалу. 3 моменту приєднання Закарпаття до складу ЧСР адміністративним органом краю стало Цивільне управління в Ужгороді, у складі якого було створено відділ (чеськ. referát) охорони здоров'я. Одним із пріоритетних напрямків його діяльності був розвиток лікарень в Мукачеві, Ужгороді, Берегові та Севлюші. Так, згідно з інформацією Президії Цивільного управління від 2 жовтня 1919 р., міську лікарню в Мукачеві було передано у державне управління. Ії директором та головним лікарем призначено д-ра Богуслава Алберта (MUDr Bohuslav Albert, 1890-1952). Щоправда, на той час він ще не приступив до роботи 5 .

Утім, того ж таки року Б. Алберт прибув до Мукачева $\mathrm{i}$ взявся втілювати в життя медичні зміни. Зауважимо, що Б. Алберт народився в чеському містечку Костелець-надОрлицею (чеськ. Kostelec nad Orlici) в поважній лікарській родині. У 1912 р. як асистент знаного чеського лікаря й мецената, проф. Рудольфа Єдлічки (1869-1926) перебував на сербському фронті. Під час Першої світової війни Б. Алберт трудився в різних військових хірургічних бригадах, де засвоїв методи лікування віденської медичної школи. Отже, коли він потрапив на Підкарпатську Русь, то, попри молодий вік, уже мав неабиякий досвід роботи в медичній сфері.

На той час Мукачівська лікарня, якою до встановлення чехословацької влади опікувалася місцева громада, знаходилася в занедбаному стані. Вона складалася 3 двох білыших двоповерхових корпусів і трьох менших одноповерхових будівель. Головний корпус лікарні було зведено в 1863 р. і він спочатку призначався винятково для проживання. Згодом його було адаптовано для потреб лікарні, а в 1898 р. тут було навіть добудовано ще один поверх. Та попри це, будівля не відповідала медичним вимогам. Тут знаходилися дві більші зали і сім малих палат. В них можна було розмістити 92 ліжка. У цьому ж корпусі знаходилася канцелярія, амбулаторне приміщення 3 операційною залою, лабораторія і рентгенологічний пристрій. У 1904 р. було зведено двоповерховий хірургічний корпус, який, щоправда, виявився досить непрактичним. На першому поверсі будівлі було розміщено операційну залу i невелике пологове відділення з 3-ма палатами та 14-ма ліжками. На другому ж поверсі розташовувалася велика зала на 20 хворих, яку не було розділено окремо для осіб чоловічої й жіночої статі, і 5 малих палат на 7 ліжок. Згодом у дворі лікарні було споруджено невеликий павільйон на 22 ліжка для жінок із венеричними захворюваннями.

Мукачівська лікарня освітлювалася 3 допомогою електроенергії, воду отримувала 3 кількох власних колодязів. В гігієнічному плані ця вода не була шкідлива для пиття. Однак у незадовільному стані була система каналізаціїЗагалом обладнання Мукачівської лікарні було досить бідним ${ }^{6}$. Хоча вона могла лікувати 120 недужих, станом на осінь 1919 р. тут надавали медичну допомогу заледве 50 пацієнтам. Хворі уникали цієї лікарні, де майже все було покладено на плечі черниць (мабуть, ордену "Сестри милосердя ім. св. Вікентія" - І.Л.). Про роботу лікарів свідчить той факт, що операційну залу черниці використовували як кімнату для квітів. Амбулаторне лікування бідних узагалі не проводилося. В інфекційному відділенні, яке нашвидкуруч було облаштоване в колишній халупі для наймитів домінії графа Шенборна, хворі на скарлатину, дифтерію, черевний тиф та інші недуги лежали без жодної ізоляції. Ймовірно, лікар туди ніколи не приходив. На вечерю черниці не давали маленьким дітям ${ }^{7}$. до сухої їжі нічого пити, щоб ті не заважали їм вночі спати.

Отже, новому очільникові Мукачівської лікарні доводилося починати ледь не 3 нуля. При цьому потрібно було зважати на соціально-лікарську базу й трудитися, не покладаючи рук. Щоправда, активно підтримували Б. Алберта як у Міністерстві охорони здоров'я й фізичного виховання, так і в Цивільному управлінні в Ужгороді. Заслуговує на увагу й той факт, що 9 квітня 1920 року Національні збори ЧСР ухвалили закон № 242, який підтвердив одержавлення Мукачівської лікарні ${ }^{8}$.

У своїй діяльності Б.Алберт знайшов підтримку в особі д -pa Вацлава Пейше (MUDr Václav Pejše, 1891 - 1969), такого ж молодого й здібного фахівця, як і він сам. У стислі строки їм вдалося докорінно оновити Мукачівську лікарню, належним чином відремонтувати окремі відділення, а деякі 3 них навіть реконструювати. Зокрема було повністю перебудовано оглядове відділення та обладнано лабораторію. Стала повноцінно функціонувати амбулаторія, в якій могли отримувати медичну допомогу навіть незаможні пацієнти. У 1922 р. було відкрито нове інфекційне відділення. Відтак було зведено сучасні корпуси, зокрема, відділення для немовлят та хірургічного, який очолював Б. Альберт. Суттєво збільшився персонал Мукачівської лікарні, яка стала працювати системно, а характер іiі роботи дедалі більше набував клінічних форм. Зусиллями Б. Алберта та В. Пейше, якого в 1923 p. було призначено завідувачем терапевтичного відділення, Мукачівська лікарня досягла справді високого рівня з надання медичних послуг 9 .

\footnotetext{
${ }^{4}$ Turak Y. Yatsyna Yu. Dokumentalna istoriia likarni imeni Andriia Novaka v Uzhhorodi: (z naidavnishykh chasiv do nashykh dniv): u 3 t., T. 1. Rozvytok ta diialnist likarni pid kerivnytstvom Andriia Novaka (1874-1928), [Documentary history of the Andriy Novak Hospital in Uzhhorod: (from ancient times to the present day): in 3 vols, Vol. 1, Development and activity of the hospital under the direction of Andriy Novak (18741928)], Uzhhorod, Patent, 2016, 624 p. [in Ukrainian].

${ }^{5}$ Derzhavnyi arkhiv Zakarpatskoi oblasti (DAZO) [State Archives of the Transcarpathian region], F. 29, Op. 3, Spr. 3, 6 ark. [in Czech].

${ }^{6}$ Dr. Doškár. "Veřejné zdravotnictví v Podkarpatské Rusi. II" [Public health care in Subcarpathian Rus. II], Národní listy [National leaves], Praha, 11, zárí 1921, Ročník 61, Číslo 249, P. 9 [in Czech].

${ }^{7}$ Doškáŕ J. "Veřejné zdravotnictví v Podkarpatské Rusi" [Public health care in Subcarpathian Rus. II], Podkarpatská Rus: obraz poměrů prirrodnich, hospodárských, politických, cirkevnich, jazykových a osvětových [Subcarpathian Rus. Proceedings of economic, cultural and political knowledge of Subcarpathian Rus], Praha: Orbis, 1923, P. 178 [in Czech].

${ }^{8}$ Č́s. 242. Zákon zed ne 9.dubna 1920 o prozatímní úpravě právních poměru ústavů léčbných a humanitních v republice Československé [N 242. Act of No Sun of April 9, 1920 on the Provisional Regulation of the Legal Conditions of Medical and Humanitarian Institutes in the Czechoslovak], Sbirka zákonů a nařizeni státu československého [Collection of laws and regulations of the Czechoslovak state], Ročník 1920, Částka XLVI, P. 532 [in Czech].

${ }^{9}$ Albert B. "Několik vzpomínek na mukačevskou nemocnici a na práci v Podkarpatské Rusi” [Some memories of Mukachevo Hospital and work in Subcarpathian Russia], Věstnik českých lékařu [Bulletin of Czech doctors], Praha, 23 května 1930, Ročník XXXXII, Číslo 21, P. 518-520 [in Czech]; Pinta A. "Zdravoochranenije" [Health care], Novoje vremja. Nezavisima političeska gazeta Podkarpatskoj Rusi, Hod izdanija V, Užhorod, dňa 10 maja 1929, No. 18-19 (Jubilejnyj nomer) [in Russian]; Bakala J. "75. výročí založení Bat’ovy
} 
Саме в Мукачеві у період з 4 по 7 червня 1922 р. було проведено представницький соціально-лікарський з’їд, організатором якого стала Підкарпатська жупа Центральної спілки чехословацьких лікарів (Ústředni jednota československých lékařŭ, ÚJČL). Керував роботою форуму головний лікар Дитячого будинку в Мукачеві д-р Йозеф Франтал (MUDr Josef Frantál, 1892 - 1961), а генеральним секретарем зібрання був Б.Алберт. У засіданнях з"їзду взяло участь 109 лікарів-терапевтів з усіх куточків Чехословацької республіки. На форум до Мукачева прибули також такі відомі професори медицини, як Антонін Веселий (Antonín Vesely) 3 Праги, Рудольф Ванисек (Rudolf Vanýsek) з Брна, Вітєзслав Хлумський (Vitězslav Chlumský), Роман Кадлицький (Roman Kadlický) та Станіслав Костливий (Stanislav Kostlivy) всі троє 3 Братислави. Заслуговує на увагу той факт, що Б.Альберт надіслав запрошення навіть очільникові уряду й міністрові закордонних справ Едварду Бенешу, міністру охорони здоров'я та фізичного виховання Богуславові Врбенському, міністрові шкільництва і народної освіти Вавро Шробару.

Почесним головою з'їзду було обрано проф. А. Веселого. Робота форуму проходила в шести секціях: 1 соціальна фізіологія, патологія та гігієна дитячого віку; 2 етіологія і класифікація каліцтв, піклування про інвалідів; 3 нагляд за хронічними невиліковними хворобами; 4 - стан соціально-гігієнічної проблеми туберкульозу; 5 - опіка хворих $з$ психічними розладами та проблема алкоголізму; 6 - загальні проблеми медицини. В численних грунтовних доповідях було також обговорено i результати впровадження соціальнолікарської опіки на Підкарпатській Русі ${ }^{10}$.

Слід відзначити, що Б. Алберт з великим ентузіазмом ставився до роботи, проявляв постійну турботу про своїх пацієнтів, більшість 3 яких становили незаможні жителі Підкарпатської Русі. Він пропрацював у Мукачеві до 1927 р. Весною того ж року Б. Алберт переїхав у моравське місто Злин (чеськ. Zlín). Зуважемо, що з 1923 р. його мером був відомий чеський підприємець Томаш Батя (1876-1932). Наприкінці XIX ст. він заснував у Злині взуттєву фабрику, яка згодом перетворилася на потужну фірму “Т. \& A. Bat'a”. У 1926 р. у “Віснику чеських лікарів” було надруковано оголошення про те, що фірма “Т. \& A. Вat'a” хоче побудувати в Злині сучасну лікарню і шукає молодого та енергійного фахівця 3 різних галузей медицини, який зміг би зайнятися цією справою. Тож Б.Алберт не оминув таку пропозицію і перебрався в Злин, де взявся за розбудову лікарні. Уже 21 листопада 1927 р. вона прийняла свого першого пацієнта. Так у Злині постала знаменита Батьова лікарня. 31927 р. Б. Альберт працював головним лікарем, а згодом і директором цієї установи.

Після від”їзду Б.Альберта з Мукачева головним лікарем місцевої лікарні став В.Пейше, а завідувачем хірургічного відділення - Алоїз Ружичка (MUDr Alois Rưzička, 1887 - ?) $)^{11}$. У 1929 р. в Мукачівській лікарні було 249 ліжок. На той час тут працювали 1 головний лікар, 7 лікарів-асистентів, 2 позаштатні лікарі, а також функціонували такі відділення, як терапевтичне, хірургічне, гінекологічне, туберкульозне, інфекційне та шкірних хвороб ${ }^{12}$.

Щодо міста Ужгорода, то лікарня тут тривалий час була приватною і тільки 1 січня 1870 року вона отримала статус громадського медичного закладу. 31 січня 1874 р. лікарню очолив д-р Андрій Новак (1850-1939), зусиллями якого іiї було суттєво розбудовано. Передусім зведено головний корпус лікарні, який згодом вдалося ще й розширити. В результаті, з'явилася можливість рятувати життя більшій кількості пацієнтів. Якщо на момент обрання А. Новака директором лікарня налічувала всього 4 палати і 60 ліжок, то через деякий час тут можна було розмістити вже 200 хворих. У 1890 р. при Ужгородській лікарні було відкрито школу акушерок, яку теж очолив А. Новак. Відтак 1912 р. було здано в експлуатацію невеликий інфекційний павільйон на 21 ліжко. Наступного року було зведено триповерховий хірургічний корпус, схожий на санаторій - із сонячними верандами й терасами для пацієнтів (на 215 ліжок). У 1914 р. було завершено будівництво триповерхового психіатричного корпусу, який міг лікувати від 150 до 200 хворих. Та позаяк розпочалася Перша світова війна, тут знаходився лазарет для поранених і хворих воїнів. 31879 р. догляд за хворими здійснювали черниці ордену “Сестри милосердя ім. св.Вікентія",

Після утвердження в Ужгороді чехословацької адміністрації лікарня продовжувала надавати медичну допомогу не лише містянам, але й жителям інших регіонів Підкарпатської Русі. Це була єдина лікарня краю, яка завдяки дру А.Новаку знаходилася в дещо кращому стані, ніж інші. Щоправда, й тут було чимало проблем. У 1920 р. Ужгородську лікарню перевіряла спеціальна комісія, яка дійшла висновку, що господарство закладу не витримує жодної критики. Члени комісії констатували, що інвентарні книги не велися і не було жодних записів про те, скільки витрачалося коштів на харчі, дрова, вугілля та медичні препарати; всі придбання здійснювалися за значно вищими цінами, ніж приватна особа купує в роздріб; обслуговуючий персонал утримувався в понаднормативному штаті; лікарську роботу було занедбано, амбулаторне лікування здійснювали здебільшого черниці;

nemocnice" [75th anniversary of the founding of Bat’a Hospital], Batova nemocnice ve Zlíne 1927-2002 [Bat’a Hospital in Zlín 19272002], koordinoval (sestavil) Jiř́i Bakala. Zlín: Bat’ova krajská nemocnice, [2003], P. 18 [in Czech]; "Z pamětí prof. MUDr. Emericha Poláka, Dr.Sc." [From the memory of prof. MUDr. Emerich Polák, Dr.Sc], ed. Ludmila Hlaváčkova - Hana Mášová, Práce z dějin Akademie věd [Works from the history of the Academy of Sciences], 2010, Ročník 2, Č. 2, P. 141-142. [in Czech]; Hrbek A. Podkarpatská Rus: stoleté výročí vzniku [Subcarpathian Rus: the centenary of its origin], Olomouc: Poznání, 2018, P. 197-198 [in Czech].

10 “Sociálně-lékařský sjezd v Mukačevě (Oficielní zpráva.)" [Socio-medical congress in Mukachevo (Official report.], Věstník českých lékařu [Bulletin of Czech doctors], Praha, 24 června 1922, Ročník XXXIV, Číslo 25, P. 312-314 [in Czech]; "Sociálně lékařský sjezd v Mukačevě" [Socio-medical congress in Mukachevo], Věstník ministerstva veřejného zdravotnictví a tělesné výchovy [Journal of the Ministry of Public Health and Physical Education], Praha, 20 července 1922, Ročník IV, Č́íslo 7, P. 301-302 [in Czech]; "Ze sociálnělékařského sjezdu v Mukačevě” [From the socio-medical congress in Mukachevo], Český svět [Czech world], Illustrovaný čtrnáctidenník, 10 srpna 1922, Ročník XVIII, Číslo 46, P. 740-741 [in Czech]; Bakala J. “75. výročí založení Bat’ovy nemocnice...”, op. cit., P. 18.

${ }^{11}$ Bakala J. “75. výročí založení Bat’ovy nemocnice...”, op. cit., P. 16-19; “Z pamětí prof. MUDr. Emericha Poláka, Dr.Sc...”, op. cit., P. 143; Hrbek A. Podkarpatská Rus: stoleté výročí vzniku..., op. cit., P. 198.

${ }^{12}$ Zdravotnická ročenka československá [Czechoslovak Medical Yearbook], Praha, 1929, Ročník II, P. 516 [in Czech].

${ }^{13}$ Dolinay N. "Obshchestvennaya gorodskaya bol'nitsa v Uzhgorode" [Public city hospital in Uzhgorod]. Podkarpatskaya Rus' za gody 1919 - 1936 [Subcarpathian Rus during the years 1919-1936], red. E.S. Bachinskiy. Uzhgorod": Shkol'naya pomoshch', 1936, P. 79-80 [in Russian]; Vakula N.S. "Andrii Novak - fundator Zakarpatskoi oblasnoi klinichnoi likarni. Do 165 richnytsi z dnia narodzhennia...”, op. cit., P. 303-304; Doškář J. Veřejné zdravotnictví v Podkarpatské Rusi. Přednáška [Public health care in Subcarpathian Rus. Lecture], Užhorod: Ždímal a Vetešník, 1921, 14 p. [in Czech]; Dr. Doškáŕ "Veřejné zdravotnictví v Podkarpatské Rusi. I" [Public health care in Subcarpathian Rus. I], Národni listy [National leaves], Praha, 21 srpna 1921, Ročník 61, Č́slo 228, P. 10 [in Czech]. 
лікарі звели регулярні огляди хворих у відділеннях до однієїдвох годин на день ${ }^{14}$. В результаті, у квітні 1920 р. для забезпечення раціонального управління в Ужгородській лікарні було ліквідовано медичну раду i призначено урядового уповноваженого. Відтак відбулося поступове цілеспрямоване оновлення як внутрішнього господарства, так і сфери медичного обслуговування ${ }^{15}$.

До 1928 р. директором лікарні та акушерської школи залишався А. Новак. Після його відходу на пенсію лікарню тимчасово очолив д-р Алоіз Пінта (MUDr Alois Pinta) ${ }^{16}$. Упродовж 20-х років зростало й кадрове забезпечення лікарні. Так, станом на 1921 р. Ужгородська лікарня могла приймати від 550 до 600 хворих. На той час тут, крім директора А. Новака, працювали 2 головні лікарі та 2 лікарі-асистенти. Допоміжний персонал тоді складався з 27 сестер-монахинь, 9 світських медсестер та 20 санітарок ${ }^{17}$. У 1929 р. в Ужгородській лікарні було 574 ліжка й повноцінно функціонували такі відділення, як венерологічне, гінекологічне, хірургічне, терапевтичне, інфекційне та психіатричне. Крім д-ра Алоіза Пінти, на той час тут трудилося 5 головних лікарів, 4 лікарі-асистенти, 1 помічник лікаря-асистента, 3 позаштатні лікарі, 2 лікарі-ординатори та 1 прозектор (паталогоанатом). Лікарня мала статус міської ${ }^{18}$.

Упродовж 20-х років XX ст. відбулися зміни і в школі акушерок, що існувала при Ужгородській лікарні. Розпорядженням міністерства охорони здоров'я й фізичного виховання для проживання курсанток було засновано інтернат, який певний час знаходився у підвальному приміщенні будівлі школи, зведеної 1894 року. Малозабезпечені слухачки стали отримувати стипендії, яких вистачало на харчування, проживання, утримання й дорожні витрати. До 1 березня 1927 р. директором школи був д-р А.Новак. Після того, як він вийшов на пенсію, то заклад очолив Володимир Нємец (Dr. V.Němec). Того ж року в школі було проведено внутрішній ремонт: оновлено систему електричного освітлення, проведено телефон і сигналізацію, полагоджено підлогу, викладено білим облицювальним кахлем породільний покій, вимуровано кахельні печі. Акушерська школа отримала статус училища ${ }^{19}$.

В Берегові основні корпуси лікарні було зведено наприкінці XIX ст. біля міського саду. Це були переважно одноповерхові будівлі, здебільшого муровані. Однак приміщення в них були затісними. Тут розміщувалися такі відділення: внутрішніх хвороб (50 ліжок), хірургічне (24 ліжка), гінекологічне (14 ліжок), психіатричне (16 ліжок) та венеричних захворювань (36 ліжок). Під час Першої світової війни німці спорудили на території лікарні три дерев'яні бараки. Щоправда, зведені вони були прямо на землі без фундаменту. Та попри це, тут також розміщували пацієнтів. У двох бараках можна було поставити по 22 ліжка, а третій розрахований на 38 хворих. Біля бараків знаходилася дезінфекційна станція.

У 1920 р., коли в Берегівській лікарні з'явилися чеські медики, іiі обладнання було убогим. В операційній залі, яка мала примітивне освітлення, не було справного стерилізаційного пристосування. В лабораторії не було мікроскопа, і лише кілька пробірок на столі свідчили про те, що тут повинні робитися якісь аналізи. В лікарні не було ні водогону, ні каналізації, ні належним чином облаштованих туалетів. Нечистоти у всіх будівлях скидували у бляшані посудини об'ємом 1/2 гектолітра (50 літрів) і два рази на день найнятий ром вручну виносив їх до вигрібної ями на задньому дворі лікарні. Так тривало роками, тож уся задня частина огорожі була просотана фекаліями. Ліжка були саморобні із солом'яними матрацами. Утім навіть таких ліжок не вистачало, як, до речі, і білизни. Опалення було пічне, але застаріле, тож дим часто наповнював як приміщення, так i коридори. Потріскана й закопчена димом штукатурка обсипалася, а в щілинах розмножувалися комахи ${ }^{20}$.

У плані надання медичної допомоги Берегівська лікарня теж не відзначалася відповідним рівнем. Вона була радше приватною ординацією директора, ніж лікувальним закладом. За прийом на лікування в стаціонар хворої людини тут брали плату. Якщо йшлося про бідну людину, то іï, зазвичай, залишали напризволяще. Траплялися випадки, коли протягом 5 місяців лікар жодного разу не оглядав незаможного хворого, а 3 венеричного відділення було відпущено жінку з тримісячним немовлям, а лікування небезпечної інфекції навіть не було розпочато ${ }^{21}$. Все це аж ніяк не відповідало завданням лікарні й тим вимогам, які ставилися до медичного закладу.

Саме в таких умовах довелося розпочинати роботу новій адміністрації Берегівської лікарні. Велику роль у їі санації відіграв д-р Святополк Веселий (MUDr Svatopluk Veselý, 18951984). Він народився 13 липня 1895 р. в містечку Бенешів (Benešov), що неподалік Праги, у відомій родині Франтішка та Мілади Веселих. Крім нього, подружжя мало ще одного сина та двох доньок. До Першої світової війни батько Святополка був старостою Бенешова та членом Чеської державно-правової прогресивної партії. Після війни Франтішек Веселий вступив у партію національних соціалістів, яку очолював Вацлав Клофач, у 1919 - 1920 роках був міністром правосуддя в уряді Властимила Тусара. У 1920 р. він став сенатором, а згодом юрисконсультом i фінансовим радником президента Т-Г. Масарика, з яким здавна приятелював. Натомість Мілада Весела підтримувала дружні стосунки 3 дружиною президента Шарлотою Масариковою, і навіть видала окремою брошурою свою лекцію про неї ${ }^{22}$.

Син Святополк був другою дитиною Франтішка та

\footnotetext{
${ }^{14}$ Doškář J. Veřejné zdravotnictví v Podkarpatské Rusi..., op. cit., P. 178.

${ }^{15}$ DAZO, F. 29, Op. 3, Spr. 706, 67 ark. (zv.) [in Czech].

${ }^{16}$ Dolinay N. "Obshchestvennaya gorodskaya bol'nitsa v Uzhgorode...”, op. cit,, P. 80.

${ }^{17}$ Dr. Doškáŕ "Veřejné zdravotnictví v Podkarpatské Rusi. I...”, op. cit., P. 10.

${ }^{18}$ Zdravotnická ročenka československá, Ročník II..., op. cit., P. 516.

${ }^{19}$ Němec V. "Štátna babská škola v Užhorodě” [State Babská škola in Uzhhorod], Věstník českých lékař̀ [Bulletin of Czech doctors], Praha, 23 května 1930, Ročník XXXXII, Číslo 21, P. 520 [in Czech]; Nemets V. "Razvitie akusherstva na Podkarpatskoy Rusi" [Development of obstetrics in Subcarpathian Rus], Podkarpatskaya Rus' za gody 1919-1936 [Subcarpathian Rus during the years 1919-1936], red. E.S. Bachinskiy. Uzhgorod: Shkol'naya pomoshch', 1936. P. 77-78 [in Russian]; Vakula N. S. "Andrii Novak - fundator Zakarpatskoi oblasnoi ...”, op. cit., P. 304.

${ }^{20}$ Veselyy Sv. "Pyatnadtsat' let zemskoy bol'nitsy v Beregove" [Fifteen years of the Zemsky Hospital in Beregov], Podkarpatskaya Rus' za gody 1919-1936 [Subcarpathian Rus during the years 1919-1936], red. E.S. Bachinskiy, Uzhgorod: Shkol'naya pomoshch', 1936, P. 83 [in Russian]; Dr. Doškáŕ “Veřejné zdravotnictví v Podkarpatské Rusi. II...", op. cit., P. 9.

${ }^{21}$ Doškář J. "Veřejné zdravotnictví v Podkarpatské Rusi...”, op. cit,, P. 178-179.

${ }^{22}$ Brejcha M. Právník a politik JUDr. František Veselý (1863-1935) [Lawyer and politician JUDr. František Veselý (1863-1935)], Diplomové práce FF UK, Praha, 2008, 192 p. [in Czech]; Veselá M. Charley G. Masaryková, Praha: Svaz národního osvobození, 1926, 47 p. [in Czech]; Sekanina J. "Primáŕ MUDr Svatopluk Veselý padesátníkem" [Mayor Svatopluk Veselý, 50 years old], Časopis lékar̆u českých [Journal of Czech doctors], Praha, 1945, Ročník LXXXIV, Č́slo 29, P. 1051 [in Czech].
} 
Мілади Веселих. Хлопець закінчив медичний факультет Празького університету й поглиблював свої знання в клінічних установах Парижа й Берліна. Найкращі роки свого життя Святополк Веселий присвятив розбудові системи охорони здоров'я на Підкарпатській Русі як директор i головний лікар Берегівської державної лікарні. Прибувши в Берегово, він відразу ж активно взявся за нелегку справу. Передусім потрібно було забезпечити надійне фінансування лікарні. Молодий керівник знайшов порозуміння у відповідних відділах Міністерства охорони здоров'я та фізичного виховання, яке постійно допомагало організаційно, грошовими засобами та підтримувало його морально. В результаті, було відремонтовано приміщення лікарні, закуплено ліжка, білизну, медичні інструменти, рентгенапарат. Відтак зросла чисельність медичного персоналу. Увесь колектив лікарні став перейматися проблемами пацієнтів і робити все для того, аби вони отримувати належну медичну допомогу ${ }^{23}$.

Стараннями С. Веселого лікарня перетворилася в модерний медичний заклад. У 1929 р. вона мала статус крайової. В лікарні налічувалося 255 ліжок і функціонували такі відділення, як гінекологічне, пологове, терапевтичне, хірургічне, інфекційне, венерологічне. Крім С. Веселого, у штаті закладу працювало двоє головних лікарів і троє лікарівасистентів. Одна посада лікаря-асистента була вакантною ${ }^{24}$. Як і його батько, Святополк Веселий був членом партії національних соціалістів і очолював іiі осередок у Берегові ${ }^{25}$. У 1938 р. перед приходом угорців він евакуювався до Моравської Острави, де й пережив Другу світову війну ${ }^{26}$.

У травні 1920 р., перед відходом румунської адміністрації, чехословацька державна комісія оглянула лікарню у Великому Севлюші. Вона мала з'ясувати збитки, завдані румунами. Члени комісії констатували, що лікарня добре забезпечена білизною і лікарськими приладами та утримується в чистоті й порядку. Тодішній очільник лікарні д -р Калман Надь (Naggy Kalman) не виявив жодних недоліків ${ }^{27}$.

Щоправда, Севлюська лікарня була забудована лише частково. Вона складалася 3 двох невеликих одноповерхових корпусів хірургічного відділення, з'єднаних дерев'яним переходом. Один призначався для чоловіків (28 ліжок), а інший - для жінок (30 ліжок). Тут були дві операційні зали (септична й асептична), які мали досить добре устаткування. Біля рентген-апарату знаходився також пристрій Фінсена. Для лікування внутрішніх захворювань слугували дві дерев'яні споруди, поставлені під час війни, які не мали достатнього обладнання. Дитяче відділення містилося в колишньому житловому будинку, куди не проступало достатньо денного світла. Його приміщення виходили на північ, а з південного боку до них прилягала засклена веранда. Венерологічне відділення, що налічувало 24 ліжка, знаходилося в окремій будівлі 3 низькою стелею і невеликими палатами, в яких раніше проживали наймані робітники. На території лікарні у мурованій хаті малих розмірів мешкав також ії очільник. Згодом тут було розміщено інфекційне відділення на 14 ліжок. Севлюська лікарня освітлювалася електрикою, яку подавала місцева електростанція. Питну воду, досить добру, забезпечували 4 колодязі. Стічні відходи накопичувалися в резервуарах і вивозилися на возах ${ }^{28}$.

У вересні 1920 р. стали поширюватися скарги на безлад у лікарні у Великому Севлюші. На початку жовтня очільник відділу охорони здоров'я провів тут ревізію і був вражений побаченим. На сходах хірургічного відділення було розлито сечу 3 частинками екскрементів. Все це виливалося 3 нечищених і переповнених туалетів. У ванній кімнаті, яка замінювала туалети, ванна на $2 / 3$ була заповнена нечистотами. Палати ніхто не прибирав і сміття не підмітав. Жодне ліжко не було заправлене білизною чи покривалом. Солом'яні матраци були просякнуті людськими випорожненнями. Хворі, які лежали в своєму лахмітті, мали воші. Повітря в приміщеннях було настільки затхлим i задушливим, що викликало нудоту.

Директор лікарні д-р Калман Надь тоді перебував у Празі. Його заступник - лікар-асистент д-р Купфершмід (Kupferchmied) пояснював таку ситуацію відсутністю допоміжного персоналу й крадіжками. Мовляв, коли пацієнтів виписують із лікарні, то вони забирають із собою білизну й покривала. При цьому, д-р Купфершмід не зміг пояснити, чому сторожа на воротах не перешкоджає цьому. Виявилося, що очільник лікарні К. Надь теж не виконує свої повинності та у всьому шукає власну вигоду. Він ніколи не оперуватиме незаможного пацієнта, поки той йому не заплатить. Так К. Надь робив і раніше. Від багатих хворих, як з'ясувалося при перевірці, він збирає дуже високу плату, що становить кілька тисяч Кч 3 кожного. При цьому утримує таких пацієнтів на рівні третього тарифу, згідно 3 яким на одного хворого раніше виділялося 10 , а тепер - 15 Кч. Тобто К. Надь робить усе, аби в такий спосіб дискредитувати Чехословацьку республіку, до якої ставиться з ненавистю. Він запевняв, що ніколи не присягатиме їй на вірність і очікує лише на війська адмірала Горті, які повалять чехословацьку владу.

Відтак констатувалося, що К. Надь не справляється 3 обов'язками керівника медичного закладу і головного лікаря хірургічного відділення. Методи його роботи як хірурга застарілі, а лікарські пізнання досить обмежені. У відділеннях він буває раз у два тижні, 3 хворими поводиться дуже брутально, не здійснює обхід пацієнтів, хіба іноді огляне за потреби хірургічного втручання. Досить часто з'являється на роботі в нетверезому стані, часто б'є ногою доглядальниць і хворих, чи дає їм ляпаси. Стравування хворих і допоміжного персоналу дуже погане. Немає столових приборів, а на кухні для розмішування страв використовуються дерев'яні палиці. Очільник закладу економить на харчуванні хворих, а заощаджені в такий спосіб кошти витрачає на інші цілі. Він купує різне дороге приладдя, яке лікарня не потребує. Багатьом хворим доводилося і по 14 днів чекати на операцію, хоча це неприпустимо. Внаслідок зволікання результат від іï проведення був не такий позитивний або навіть смертельний ${ }^{29}$.

Справжнім лікарським раритетом виявився д-р Купфершмід, помічник К. Надя. Донедавна він був міським

\footnotetext{
${ }^{23}$ Veselyy Sv. "Pyatnadtsat' let zemskoy bol'nitsy v Beregove...", op. cit., P. 84; Sekanina J. "Primář MUDr Svatopluk Veselý padesátníkem...", op. cit., P. 1051.

${ }^{24}$ Zdravotnická ročenka československá, Ročník II..., op. cit., P. 516.

${ }^{25}$ DAZO, F. 29, Op. 3, Spr. 379, ark. 58 (zv.) [in Czech].

${ }^{26}$ Sekanina J. "Primáŕ MUDr Svatopluk Veselý padesátníkem...”, op. cit., P. 1051-1052.

${ }^{27}$ Pravda o poměrech v župní nemocnici ve Velké Sevljuši [The truth about the situation in the county hospital in Velká Sevljuš], Národní listy [National leaves], Praha, 7 července 1921, Ročník 61, Č́slo 184, P. 4 [in Czech].

${ }^{28}$ Dr. Doškáŕ "Veřejné zdravotnictví v Podkarpatské Rusi. II...", op. cit., P. 9.

${ }^{29}$ Pravda o poměrech v župní nemocnici ve Velké Sevljuši..., op. cit., P. 4; Doškář J. "Veřejné zdravotnictví v Podkarpatské Rusi...”, op. cit., P. 179
} 
лікарем, але через ворожі висловлювання проти держави окружне управління звільнило його з посади. Як з'ясувалося в ході ревізії, д-р Купфершмід видав свідоцтво про смерть дитини, яка не померла, а продовжувала жити. Так само, як і К. Надь, він бив пацієнтів, а на свого хворого родича, який нарікав на нелюдське ставлення, наставив ножа. Викриті неподобства суперечили карному закону і були передані до суду. До винесення відповідного рішення і очільника лікарні і його помічника тимчасово відсторонили від виконання білышості функцій.

Весною 1921 р. д-р Купфершмід підхопив черевниий тиф, джерелом інфекції якого виявився колодязь на території лікарні, а точніше його стічна канава для використаної води, куди зливали відходи ${ }^{30}$. Цією водою заразилася і лікаркаасистентка д-р К. Свободова (MUDr K.Svobodová). Молода лікарка мала намір влитися на службу в голландську місію на о.Ява та, зрештою, подалася на Підкарпатську Русь, щоб надавати медичну допомогу нашим краянам. До Великого Севлюша вона прибула 18 березня 1921 р. і на власні очі побачила стан тамтешньої лікарні. На той час багато недоліків не було усунуто: палати в занедбаному стані, їжа погана, всюди повно вошей, бліх і мишей. Очільник лікарні, а ним залишався К. Надь, займався особистими справами.

Попри все, К. Свободова залишилася тут працювати і за короткий час здобула повагу населення. Їй доводилося бути і лікаркою, і санітаркою, і доглядачакою. Відтак 6 квітня 1921 p. вона підготувала листа до головного лікаря д-ра Гааса (MUDr Haasz), в якому описала свої поневіряння в умовах антисанітарії. Наслідком такої роботи стало те, що К.Свободова захворіла на черевний тиф і 20 травня 1921 р. померла. Листа було надруковано у "Віснику чеських лікарів",31, а відтак на ситуацію відреагували журналісти кількох газет ${ }^{32}$. Тож усе те безчинство, що творилося в лікарні В.Севлюша, стало надбанням громадськості. Керівник медичного закладу К. Надь, аби втриматися на службі, всетаки присягнув на вірність ЧСР. Відразу ж після цього він 3 травня 1921 p. на чолі делегації угорців вирушив до президента Т.-Г. Масарика 3 вимогою, щоб на Підкарпатській Русі було звільнено, так би мовити, непридатних до служби чеських урядовців i замість них призначено міцевих посадовців. Як писали деякі видання, насправді йшлося про заміну фахових і безкомпромісних чиновників на мадяронів ${ }^{33}$. Невдовзі К. Надь підхопив черевний тиф, хоча не вважав, що його підкосила саме ця хвороба. У свою чергу відділення охорони здоров'я констатувало, що немає жодних підстав вважати його висококваліфікованим хірургом. Крім того, він виявився не компетентним у сфері гігієни й бактеріології ${ }^{34}$. Врешті-решт К. Надь був змушений покинути свою посаду.

Після всіх цих подій ситуація в лікарні у В. Севлюші стала змінюватися на краще. Станом на 1929 р. тут налічувался 201 ліжко й функціонували такі відділення, як хірургічне, терапевтичне, венерологічне та інфекційне. Лікарня мала статус крайової установи. Її керівником i головним лікарем був д-р Ян Янда (MUDr Jan Janda $)^{35}$.

Отже, за кількістю ліжок та відділень лікарня у
В. Севлюші була найменшою серед інших подібних установ Підкарпатської Русі. Відповідно, на ії утримання з бюджету виділялося й менше коштів. Так, у 1920 р. Міністерство охорони здоров'я й фізичного виховання надало 4 лікарням дотацію у сумі 2 млн Кч. Кошти було розподілено таким чином: Ужгородська лікарня отримала 1 млн 10 тис. Кч, Мукачівська - 650 тис. Кч, Берегівська -250 тис. Кч, Севлюська -90 тис. $\mathrm{Ku}^{36}$.

Як відомо, лікарні надавали допомогу й бідним верствам населення краю. У 1921 р. на ліки для незаможних краян 3 державної скарбниці було виділено 7842 Кч. А вже в 1923 р. ця сума становила вже 300000 Кч, тобто зросла більш як у 38 разів. Лікування людей, що належали до незаможних категорій населення, стало головною повинністю окружних і дільничих лікарів ${ }^{37}$.

Висновки та перспективи подалыших досліджень. 3 моменту приєднання Закарапаття до складу ЧСР органи міцевої і центральної влади приділяли значну увагу питанням охорони здоров'я місцевого населення. Важлива роль при цьому відводилася чотирьом жупним лікарням, які існували в краї ще $з$ другої половини XIX ст., але станом на 1919 рік більшість із них була в занедбаному стані і не мала належного фахового й технічного забезпечення. Виняток становила хіба що Ужгородська лікарня. Внаслідок ужитих заходів було оновлено матеріально-технічну базу лікарень. Завдяки подвижницькій праці фахівців з чеських і моравських земель суттєво покращилося медичне забезпечення жителів краю. Перспективним є вивчення питання боротьби з інфекційними хворобами, що призводили до погіршення епідемічної ситуації на Підкарпатській Русі.

Likhtei Ihor. The state of hospitals in Pidkarpatska Rus during the first decade of Czechoslovak rule (1919-1929). The article traces the process of activity of hospitals in Transcarpathia during the first decade of the land being a part of Czechoslovakia. Research methods. First of all, comparative-historical and structural-system methods of analysis, generalization and synthesis, as well as problem-chronological way of presenting the material have been used. Scientific novelty. The outlined problematics is considered in historiography for the first time. Conclusions. It is noted that at the time of the incorporation of Transcarpathia into Czechoslovakia there were four county hospitals, three of which were in a rather deplorable condition. The Czechoslovak administration had to make considerable efforts to modernize them. Emphasis was placed on the activities of doctors who came to Transcarpathia mainly from the Czech and Moravian lands. They were usually graduates of the Medical Faculty of the University of Prague, and some even underwent internships at leading European clinics. It is thanks to their ascetic work that the condition of hospitals and medical care of the population had improved.

Key words: Czechoslovak Republic, Pidkarpatska Rus, Transcarpathia, hospitals, doctors, health care, medical care.

Ігор Ліхтей - к. істор. н., доч., завідувач кафедри античності, середньовіччя та історії України домодерної доби, Ужсородський начіональний університет, Ужгород (Україна).

Ihor Likhtei - Candidate of History, Docent, Head of the Department of Antiquity, Middle Ages and History of Ukraine before the modern age, Uzhhorod National University, Uzhhorod (Ukraine).

Received: 12.05 .2021

Advance Access Published: June, 2021

(C) I. Likhtei, 2021

\footnotetext{
${ }^{30}$ Pravda o poměrech v župní nemocnici ve Velké Sevljuši..., op. cit., P. 4.

${ }^{31} \mathrm{Z}$ dopisu hrdinné lékařky [From a letter from a heroic doctor], Věstník českých lékařŭ [Bulletin of Czech doctors], Praha, 4 června 1921, Ročník XXXIII, Číslo 23, P. 337-338 [in Czech].

${ }^{32}$ Dyk V. "Obžaloba mrtvé" [Indictment of the dead], Národní listy [National leaves], Praha, 12 června 1921, Ročník 61, Číslo 159, P. 1 [in Czech]; Skandální nemocniční poměry v Podkarpatské Rusi [Scandalous hospital conditions in Subcarpathian Rus], Čas. Večerní vydání, Praha, 11 června 1921, Ročník XXXL, Číslo 130, P. 2 [in Czech].

${ }^{33}$ Věstník českých lékařu [Bulletin of Czech doctors], Praha, 4 června 1921, Ročník XXXIII, Číslo 23, P. 338 [in Czech]; Skandální nemocniční poměry v Podkarpatské Rusi..., op. cit., P. 2.

${ }_{34}^{34}$ Pravda o poměrech v župní nemocnici ve Velké Sevljuši..., op. cit., P. 4.

${ }^{35}$ Zdravotnická ročenka československá. Ročník II..., op. cit., P. 516.

${ }^{36}$ Organisace správy Podkarpatské Rusi..., op. cit., P. 71.

${ }^{37}$ Doškář J. "Veřejné zdravotnictví v Podkarpatské Rusi...", op. cit, P. 180. 